\title{
Sediments of MIS 5e age suggested by new OSL dates from the Skilvika section, west Svalbard
}

\author{
Helena Alexanderson (D) \& Jon Y. Landvik ${ }^{\mathrm{b}}$ \\ aDepartment of Geology, Lund University, Lund, Sweden; 'baculty of Environmental Sciences and Natural Resource Management, \\ Norwegian University of Life Sciences, Ås, Norway
}

ABSTRACT

The sediment succession at Skilvika, west Svalbard, represents one of the key stratigraphic records of the Late Quaternary palaeoenvironments and glaciation history of the Svalbard/ Barents Sea area. A formation of raised marine sediments, interfingering with and capped by glacial deposits of local origin, have previously been assumed to be of an Early Weichselian age, likely marine isotope stage (MIS) $5 c$. Here we present a new series of optically stimulated luminescence (OSL) ages that suggest the events took place in MIS 5e. This advocates a revision of the correlation with other key stratigraphic sites on Svalbard.

\section{KEYWORDS}

Arctic; MIS 5; glaciation

history; luminescence dating

\section{ABBREVIATIONS}

MIS: marine isotope stage OD: overdispersion

OSL: optically stimulated luminescence

$\mathrm{TL}$ : thermoluminescence

\section{Introduction}

The identification, correlation and dating of raised marine deposits formed during times with substantial glacio-isostatic depression has been, and still is, key to the reconstruction of the palaeoenvironmental and glaciation history of the Arctic (Mangerud et al. 1998; Alexanderson et al. 2014). Although such sediments are readily identified on sedimentological grounds, the stratigraphic records are often fragmented, and correlation relies heavily on numerical dating. The Svalbard-Barents Sea ice sheet is no exception, and our knowledge of its history prior to the Last Glacial Maximum is largely based on information from a limited number of key stratigraphic sites in Svalbard (Mangerud et al. 1998).

One of these sites is Skilvika, on the southern shore of Bellsund, west Svalbard $\left(77.5706^{\circ} \mathrm{N}\right.$, $14.4402^{\circ}$ E; Fig. 1, Supplementary Fig. S1), a site that has been investigated since the 1960s and most recently studied by Landvik et al. (1992). Its stratigraphic record contains three subglacial tills (Formations 1,2 and 5) and two marine-littoral units (Formations 3, 4, 6 and 7; Fig. 2), of which the uppermost till-marine succession (Formations 5-7) was deposited during the Late Weichselian (Landvik et al. 1992). This study focuses on dating Formations 3 and 4, which represent a period of high relative sea level culminating with the advance of a local glacier. Based on limited numerical dating, Landvik et al. (1992) concluded a marine isotope stage (MIS) $5 c$ age, and the sediments have been correlated to the Early Weichselian Phantomodden interstadial (ca. 100 Kya; Mangerud et al. 1998). However, this age was based only on few TL ages and mainly non-finite radiocarbon ages (Table 1, Fig. 2) (Landvik et al. 1992). The sediments have been resampled, and here we present a series of 20 OSL ages that confirm a MIS 5 age of Formation 3, but most likely MIS 5e instead of MIS $5 \mathrm{c}$.

\section{Methods}

Samples were collected in opaque bags (1997) and in opaque plastic tubes $(1999,2015)$ and were prepared and measured at the Nordic Laboratory for Luminescence Dating $(1997 / 98,1999)$ and the Lund Luminescence Laboratory (2015). Quartz grains in a range of size fractions (Table 2) were extracted by mechanical and chemical preparation. Measurements were made on large aliquots in Risø TL/OSL readers and using single aliquot regeneration protocols (Murray \& Wintle 2000; Murray \& Wintle 2003) adapted for the samples based on dose recovery and preheat plateau tests. Stimulation was with blue light for most samples but with green light for some of the samples analysed in 1998. As the measurements were made on large aliquots, final ages were calculated from the arithmetic mean dose of each sample (Guérin et al. 2017). Dose rate was determined by gamma spectrometry (Murray et al. 1987) and by accounting for the contribution from cosmic

CONTACT Helena Alexanderson helena.alexanderson@geol.lu.se @ Department of Geology, Lund University, Sölvegatan 12,22362 Lund, 


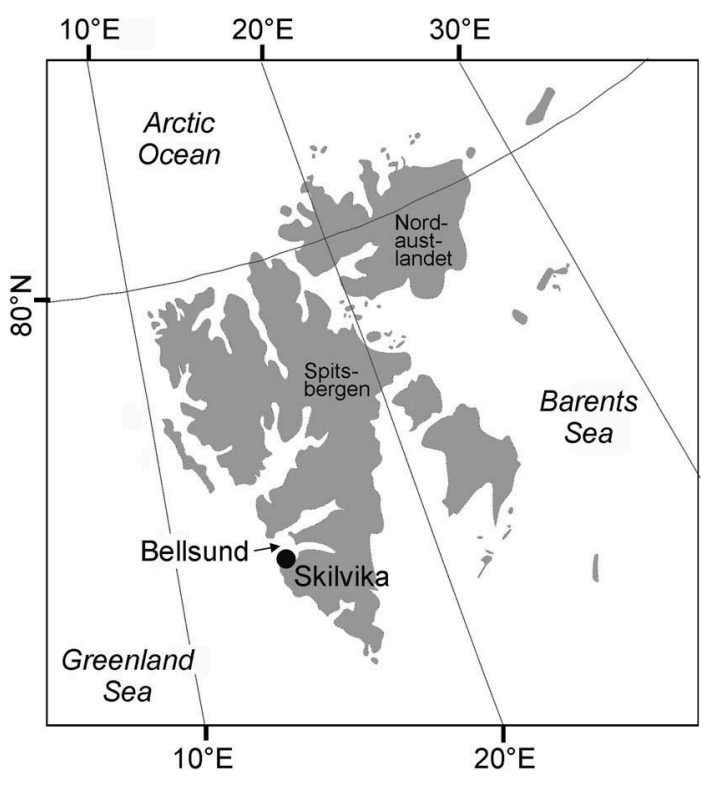

Figure 1. Location map of Skilvika, Svalbard. For more detailed location see Supplementary Fig. S1 and Landvik et al. (1992).

radiation according to Prescott \& Hutton (1994). Water content was determined in weight percent from separate samples taken next to the main sample. For age calculation it was assumed that the sediments have been saturated $95 \%$ of the time since deposition and the remaining $5 \%$ had a water content similar to that which was measured at the time of sampling. This is based on the sediments having been below sea level or below at least partially warm-based ice for much of the time since deposition, and only recently exposed along a rapidly receding coastal cliff, melted (from permafrost) and drained.

Finite radiocarbon ages from previous studies were calibrated using OxCal 4.2 online (Bronk Ramsey 2009) with the Marine13 calibration curve (Reimer et al. 2013) and assuming $\Delta \mathrm{R}=20 \pm 30 \mathrm{yr}$ (Mangerud et al. 2006).

\section{Results}

OSL ages from Formation 3 range from $263 \pm 48 \mathrm{Ky}$ to $66 \pm 5 \mathrm{Ky}$, while the single sample from the base of Formation 7 is $21 \pm 2 \mathrm{Ky}$ (Table 2). Two samples from Formation 3 are considered outliers, likely because of significant incomplete bleaching during an event with high sedimentation rate (sample 15098 at $755 \mathrm{~cm}$ ) and to a too high dose rate (sample 15099 at $840 \mathrm{~cm}$ ), respectively. Both these ages fall far outside two standard errors of the mean for all Formation 3 ages and show a mismatch in the proportional relationship of dose to dose rate compared to the other samples. Excluding these two ages, the Formation 3 age range is $149 \pm 17 \mathrm{Ky}$ to $90 \pm 7 \mathrm{Ky}$ (mean $119 \pm 5 \mathrm{Ky}, n=18$ ). Nine samples have OD values consistent with those of well-bleached multigrain aliquots (13 $\pm 7 \%$; Arnold \& Roberts 2009), while 14 samples have significantly positively skewed dose distributions (Table 2).

\section{Discussion}

The OSL ages from Formation 3 span a wide range, which at face value covers both MIS 6 and MIS 5 (Supplementary Fig. S2). The mean age, $119 \pm 5 \mathrm{Ky}$, falls within MIS 5e (the last interglacial), but within errors overlaps the stadial MIS 5d. Also, the error associated with the mean age is likely underestimating the true uncertainty given the wide age range of all samples and the broad dose distributions of individual samples. The mean age is nevertheless older than the previous TL ages $(105-90 \mathrm{Ky})$ that led Landvik et al. (1992) to prefer an Early Weichselian (MIS 5c-b) age for Formations 3 and 4, although not ruling out an Eemian (MIS 5e) age.

However, considering the spread of OSL ages (149-90 $\mathrm{Ky})$ as well as an apparent age overestimation of the Holocene sample in Formation 7 (Fig. 2), we need to look into some factors that could affect the ages. Arguments for both over- and underestimation of age can be made, and here we will evaluate the main ones. The Formation 7 sample (sample 15097 at $400 \mathrm{~cm}$ ) can be used for some assessments, since it is from sediments that represent a similar depositional environment as Formation 3 and for which we have several independent, finite radiocarbon ages from large mollusc samples.

A common cause for luminescence age overestimation in depositional environments such as those at Skilvika (glaciated landscape with high sedimentation rates) is incomplete bleaching, when the sediment is not completely reset by sunlight at the time of deposition (e.g., Fuchs \& Owen 2008; Thrasher et al. 2009). One way to assess incomplete bleaching is to compare to an independent age control. This is possible for Formation 7, but not for Formation 3. Compared to the radiocarbon age (11.0-10.6 cal. Ky BP; Table 1), the OSL age from Formation 7 appears to be about 10 Ky too old (21 $\pm 2 \mathrm{Ky}$; Table 2$)$. This sample has a significantly skewed dose distribution $(\mathrm{Sk}=1.3)$ and a high overdispersion ( $\mathrm{OD}=40 \pm 6 \%$ ), which may hint that incomplete bleaching is the cause of its age overestimation (Wallinga 2002). However, since our data are based on large aliquots, dose-distribution statistics must be treated with considerable caution on account of the averaging that occurs among the many grains making up each aliquot (Duller 2008).

If we tentatively apply this reasoning to the Formation 3 samples, we note that a majority of the samples are significantly positively skewed and/or have large OD values (Table 2), similar to the Formation 7 sample. However, some of the skewness may for these higher-dose samples be due to the shape of the dose response curve (Murray et al. 2002; Murray \& Funder 2003), rather than due to 


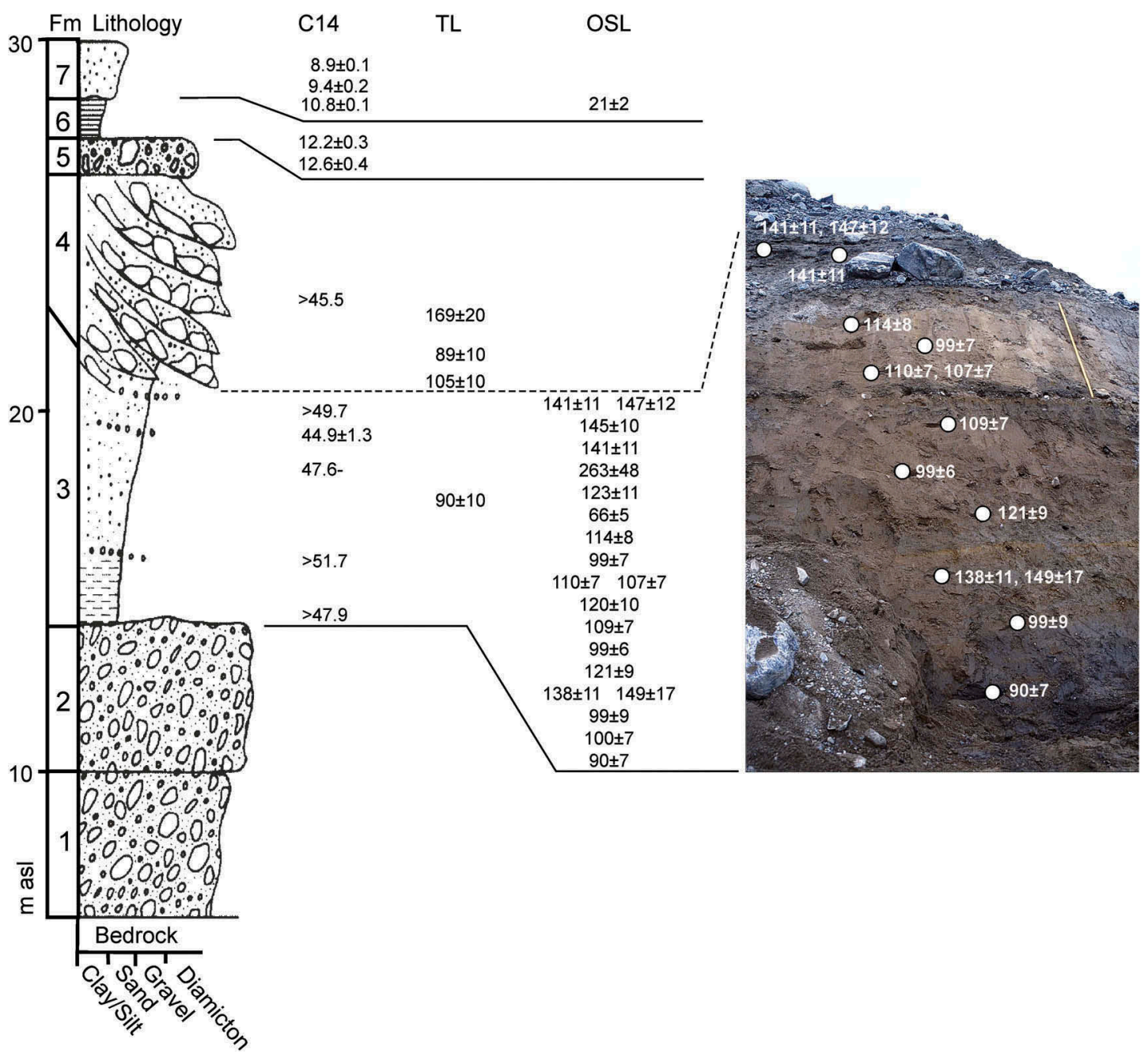

Figure 2. Composite log with luminescence (Ky) and radiocarbon ages (cal. Ky BP except for non-finite ages, which are in Ky BP) from this study and from Landvik et al. (1992). The photograph shows the positions of samples taken in 1999 only; the 2015 samples are from ca. $10 \mathrm{~m}$ to the right on the photograph, while the samples collected in 1997 are from the same unit but elsewhere in the cliff section. For details on ages see Tables 1-2, and Supplementary Fig. S2 for an age-depth plot.

Table 1. Radiocarbon ages of mollusc shells and seaweed from Skilvika, ${ }^{14} \mathrm{C}$ ages were originally published by Landvik et al. (1992) and calibrated in this study using OxCal 4.2 (Bronk Ramsey 2009) with the Marine13 calibration curve (Reimer et al. 2013). Non-finite ages have not been calibrated.

\begin{tabular}{|c|c|c|c|c|c|}
\hline Lab. id. & Formation & Species & ${ }^{14} \mathrm{C}$ age (yr BP) & Calibrated age range, $2 \mathrm{~s}$ (cal. yr BP) & Calibrated age, median (cal. yr BP) \\
\hline $\mathrm{T}-6222$ & 7 & Hiatella arctica & $9920 \pm 90$ & $9164-8675$ & $8912 \pm 128$ \\
\hline T-5998 & 7 & Mya truncata & $10260 \pm 110$ & $9802-9042$ & $9363 \pm 190$ \\
\hline T-5997 & 7 & Hiatella arctica & $11230 \pm 120$ & $11020-10565$ & $10773 \pm 114$ \\
\hline $\mathrm{T}-6000$ & 6 & Nuculana pernula & $12570 \pm 160$ & $12842-11703$ & $12196 \pm 287$ \\
\hline Ua-280 & 6 & Nuculana pernula & $12830 \pm 210$ & $13296-11955$ & $12624 \pm 361$ \\
\hline T-5993 & 4 & $\begin{array}{l}\text { Hiatella arctica, Macoma } \\
\text { calcarea }\end{array}$ & $>45500$ & & \\
\hline T-5996 & 3 & Macoma calcarea & $>49700$ & & \\
\hline T-5994 & 3 & Seaweed & $43600 \pm 1400 / 1200$ & $47731-42601$ & $44912 \pm 1340$ \\
\hline T-5796 & 3 & Hiatella arctica & $47500 \pm 2900 / 2100$ & $47630-$ & - \pm- \\
\hline T-5795 & 3 & Hiatella arctica & $>51700$ & & \\
\hline T-5999 & 3 & Hiatella arctica, Mya truncata & $>47900$ & & \\
\hline
\end{tabular}

incomplete bleaching. There are, nonetheless, also samples from Formation 3 that are not significantly skewed and that have ODs consistent with wellbleached material. By excluding assumed incompletely bleached samples (those with $\mathrm{Sk}>3 \sigma_{\mathrm{s}}$ and/or OD $>35 \%$; Table 2) and by accounting for any curverelated skewness by using the median dose for age calculation as recommended by Murray \& Funder
(2003), the mean age becomes $118 \pm 7 \mathrm{Ky}(n=10)$. This is indistinguishable from the mean age for all samples (except 15097, -98), as based on the arithmetic mean dose.

Another way to evaluate bleaching is to compare ages from different grain-size fractions. As grains with different sizes rarely have exactly the same transport path before deposition (bleaching history), they 
Table 2. OSL data including age in kiloyears (Ky), dose in Gray (Gy) and number ( $\mathrm{n}$ ) of aliquots accepted of the total number measured as well as sediment water content (w.c.) in weight percent. Samples are sorted in order of depth.

\begin{tabular}{|c|c|c|c|c|c|c|c|c|c|c|}
\hline Lab. no & Depth (cm) & Grain size $(\mu \mathrm{m})$ & Age (Ky) & Mean dose (Gy) & Median dose (Gy) & $\mathrm{Sk}^{\mathrm{a}}$ & $O D^{b}(\%)$ & $\mathrm{n} /$ total & Dose rate (Gy/Ky) & w.c. (\%) \\
\hline \multicolumn{11}{|l|}{ Formation 7} \\
\hline Lund 15097 & 400 & $180-250$ & $21 \pm 2$ & $21.4 \pm 1.8$ & 19.3 & 1.3 & 40 & $30 / 48$ & $1.03 \pm 0.05$ & 25 \\
\hline \multicolumn{11}{|l|}{ Formation 3} \\
\hline Risø 993711 & 740 & $90-150$ & $141 \pm 11$ & $142.4 \pm 8.2$ & 135.9 & 0.7 & 22 & $20 / 21$ & $1.01 \pm 0.05$ & 30 \\
\hline Risø 993711 & 740 & $250-500$ & $147 \pm 12$ & $139.5 \pm 8.1$ & 142.9 & -0.1 & 32 & $26 / 27$ & $0.95 \pm 0.05$ & 30 \\
\hline Risø 983701 & 745 & $106-212$ & $145 \pm 10$ & $135.9 \pm 5.7$ & 141.2 & -0.1 & 15 & $19 / 20$ & $0.94 \pm 0.05$ & 24 \\
\hline Risø 993710 & 750 & $90-150$ & $141 \pm 11$ & $148.1 \pm 8.2$ & 137.2 & 0.6 & 21 & $20 / 21$ & $1.05 \pm 0.06$ & 32 \\
\hline Lund 15098 & 755 & $180-250$ & $263 \pm 48$ & $272.2 \pm 47.6$ & 210.7 & 2.1 & 59 & $19 / 30$ & $1.03 \pm 0.05$ & 18 \\
\hline Risø 983703 & 800 & $106-300$ & $123 \pm 11$ & $98.2 \pm 5.5$ & 91.5 & 0.6 & 19 & $16 / 20$ & $0.80 \pm 0.06$ & 24 \\
\hline Lund 15099 & 840 & $180-250$ & $66 \pm 5$ & $94.9 \pm 4.9$ & 91.6 & 1.1 & 16 & $22 / 24$ & $1.43 \pm 0.06$ & 25 \\
\hline Risø 993709 & 850 & $90-150$ & $114 \pm 8$ & $127.3 \pm 4.9$ & 122.9 & -0.5 & 16 & $21 / 21$ & $1.12 \pm 0.06$ & 24 \\
\hline Risø 993708 & 880 & $90-150$ & $99 \pm 7$ & $122.2 \pm 5.4$ & 112.4 & 0.8 & 15 & $19 / 21$ & $1.24 \pm 0.06$ & 27 \\
\hline Risø 993707 & 910 & $90-150$ & $110 \pm 7$ & $129.2 \pm 5.7$ & 125.0 & 1.2 & 14 & $19 / 21$ & $1.17 \pm 0.05$ & 24 \\
\hline Risø 993707 & 910 & $300-500$ & $107 \pm 10$ & $116.9 \pm 9.3$ & 112.9 & 0.3 & 62 & $26 / 27$ & $1.10 \pm 0.06$ & 24 \\
\hline Lund 15100 & 965 & $180-250$ & $120 \pm 10$ & $99.8 \pm 6.7$ & 94.9 & 2.1 & 26 & $22 / 24$ & $0.83 \pm 0.04$ & 27 \\
\hline Risø 993706 & 970 & $90-150$ & $109 \pm 7$ & $124.7 \pm 4.5$ & 117.3 & 1.5 & 8 & $15 / 15$ & $1.14 \pm 0.05$ & 26 \\
\hline Risø 993705 & 995 & $90-150$ & $99 \pm 6$ & $132.0 \pm 5.1$ & 124.4 & 1.0 & 9 & $15 / 15$ & $1.33 \pm 0.06$ & 29 \\
\hline Risø 993704 & 1020 & $90-150$ & $121 \pm 9$ & $139.5 \pm 8.3$ & 131.8 & 2.7 & 15 & $14 / 15$ & $1.15 \pm 0.05$ & 27 \\
\hline Risø 993703 & 1050 & $63-90$ & $138 \pm 11$ & $159.1 \pm 9.3$ & 149.0 & 1.5 & 17 & $15 / 15$ & $1.15 \pm 0.05$ & 21 \\
\hline Risø 993703 & 1050 & $300-500$ & $149 \pm 17$ & $158.7 \pm 16.0$ & 145.0 & 0.9 & 57 & $25 / 27$ & $1.06 \pm 0.06$ & 21 \\
\hline Risø 993702 & 1080 & $90-150$ & $99 \pm 9$ & $98.3 \pm 7.2$ & 95.2 & 0.0 & 43 & $20 / 21$ & $0.99 \pm 0.05$ & 30 \\
\hline Risø 983702 & 1100 & $106-212$ & $100 \pm 7$ & $115.2 \pm 4.1$ & 110.1 & 0.5 & 24 & $51 / 57$ & $1.15 \pm 0.07$ & 24 \\
\hline Risø 993701 & 1120 & $90-150$ & $90 \pm 7$ & $99.8 \pm 6.2$ & 107.2 & 0.0 & 35 & $27 / 39$ & $1.11 \pm 0.05$ & 24 \\
\hline
\end{tabular}

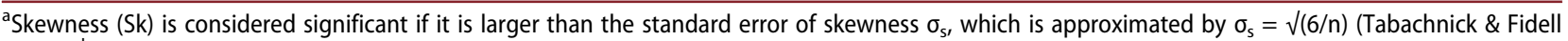
1996). ${ }^{b} \mathrm{~A}$ measure of the variance that is larger than that expected from measurement uncertainty. A value of $13 \pm 7 \%$ is considered to be consistent with well-bleached large aliquots (Arnold \& Roberts 2009).

will likely not give the same age unless bleaching was efficient in the sedimentary environment (e.g. Fuchs et al. 2005). Three of our samples have been analysed with different grain sizes, ranging from 63-90 $\mu \mathrm{m}$ to 300-500 $\mu \mathrm{m}$, and all three show agreement within error between fractions (Table 2). This would support that bleaching has been sufficient.

Systematic age underestimation by $5-10 \%$ has been shown to occur for quartz OSL ages from Eemian deposits (Murray \& Funder 2003) although the causes are not entirely understood. We cannot evaluate this factor for our data set specifically. Also, information from OSL ages from sediments correlated to the Eemian elsewhere in Svalbard is inconclusive as there are indications both of some age underestimation (Alexanderson et al. 2013) and of no apparent underestimation (Alexanderson et al. 2011; Alexanderson et al. 2018). Generally, there is a wide spread in ages for these sediments, which may be due to incomplete bleaching, poor luminescence characteristics or other causes, and which prevents resolving the age of the events in detail.

Age over- or underestimation could also be caused by an incorrectly assumed water content, which would affect the average dose rate. If too high water content has been assumed, the dose rate will be too low and the age correspondingly too high, and vice versa. In this case, we have assumed a water content for our samples that is fairly close to saturation, i.e. almost as high as possible for these sediments. If this is too high compared to the true average water content since the time of deposition, the ages are too old. If the Holocene sample 15097 from Formation 7 is taken as an example again, and its water content is lowered to be equal to that at the time of sampling $(12 \%)$, or even to the extreme of zero, only slightly younger ages of $19 \pm 2 \mathrm{Ky}$ or $17 \pm 2 \mathrm{Ky}$, respectively, are produced. This significant overestimation of the true age leads us to conclude that variation in water content cannot explain the whole age overestimation for this sample at least. Lowering the water content to present-day levels in late summer (7-17\%) for the Formation 3 samples results in an age range of $142-84 \mathrm{Ky}$. With a mean age of $104 \pm 4 \mathrm{Ky}$, this would move the deposition of Formation 3 to the Early Weichselian MIS 5d/5c transition. However, we argue that the present water content should be considered a minimum and that the true average water content (and, therefore, age) must have been higher for most of the duration.

From sedimentological and microfaunal evidence, we know that the dated sediments were deposited during a high relative sea-level event, with relatively open and saline marine conditions similar to today or slightly colder (Landvik et al. 1992; Lycke et al. 1992). This environment could represent either interstadial or non-climatic optimum (i.e., early or late) interglacial conditions, and so cannot be used to distinguish between MIS 5e and $5 \mathrm{c}$ at this site. The proglacial deposit of Formation 4, interpreted as resulting from a local glacier advance during a continued interstadial high-stand (Landvik et al. 1992), could also reflect a local ice flow style during deglaciation (Landvik et al. 2014).

As discussed above, the spread in ages as well as the large uncertainty of individual ages prevents a precise age determination of Formation 3, and both MIS $5 \mathrm{e}$ and $5 \mathrm{c}$ are within the possible age range. 
However, assuming the sediments were sufficiently bleached, the mean age places the deposition in MIS 5e.

\section{Summary and conclusions}

Twenty new OSL ages place the raised marine deposits of Formation 3 at Skilvika, west Svalbard, in the MIS 5. If two unreliable ages are excluded, the mean age of the depositional event is $119 \pm 5 \mathrm{Ky}(n=18)$, which at face value is in the later part of MIS $5 \mathrm{e}$, the last interglacial. This is older than previously suggested by Landvik et al. (1992), who placed Formation 3 in MIS 5c, although they did not exclude an Eemian (MIS 5e) age. Our interpretation is based on the assumptions that the sediments were sufficiently bleached at the time of deposition and that they have been close to (water) saturation since that time. Sufficient bleaching of Formation 3 sediments is mainly supported by the agreement of ages between different grain sizes from the same samples. However, the age range of the 18 samples is large (149-90 Ky) and the dose distributions of individual samples are broad, which gives the mean age a larger uncertainty than the $\pm 5 \mathrm{Ky}$ indicated by its numerical standard error. With this in mind, and considering the possibility of incomplete bleaching in the order of ca. 10 $\mathrm{Ky}$ as indicated by a single OSL age from the independently dated Formation 7, we cannot completely rule out an Early Weichselian interstadial (MIS 5c) age of Formation 3. However, as argued above, we prefer the older age (MIS 5e) as the most conservative conclusion based on the data. Consequently, the Formation 4 glacial deposit (Fig. 2) probably reflects a local ice flow style (Landvik et al. 2014) during deglaciation, rather than an advance of a local glacier as previously assumed (Landvik et al. 1992). A MIS 5e age also means that Skilvika is added to the group of sites in Svalbard with preserved Eemian deposits (Kapp Ekholm, Leinstranda, Kongsfjordhallet, Poolepynten), supporting the revised correlation scheme of Late Quaternary key stratigraphic sites on Svalbard suggested by Alexanderson et al. (2018).

Geolocation: $77.5706^{\circ} \mathrm{N}, 14.4402^{\circ} \mathrm{E}$

\section{Acknowledgements}

All sampling was performed during University Centre in Svalbard AG332/832 excursions, and benefited from assistance by students and teachers. Andrew Murray and the staff at the Nordic Laboratory for Luminescence Dating have provided advice on sampling and data analysis, as well as carried out measurements of most samples. Constructive comments on the manuscript were received from Anna Hughes and Teena Chauhan.

\section{Disclosure statement}

No potential conflict of interest was reported by the authors.

\section{Funding}

Dating of the 1997 and 1999 samples were made possible by a research grant from the University Centre in Svalbard to JYL.

\section{ORCID}

Helena Alexanderson (D) http://orcid.org/0000-0002-55731906

\section{References}

Alexanderson H., Backman J., Cronin T.M., Funder S., Ingólfsson Ó., Jakobsson M., Landvik J.Y., Löwemark L., Mangerud J., März C., Möller P., O’Regan M. \& Spielhagen R.F. 2014. An Arctic perspective on dating Mid-Late Pleistocene environmental history. Quaternary Science Reviews 92, 9-31.

Alexanderson H., Henriksen M., Ryen H.T., Landvik J.Y. \& Peterson G. 2018. 200 ka of glacial events in NW Svalbard: an emergence cycle facies model and regional correlations. Arktos 4(3), doi: 10.1007/s41063-018-0037-z.

Alexanderson H., Ingólfsson Ó., Murray A.S. \& Dudek J. 2013. An interglacial polar bear and an early Weichselian glaciation at Poolepynten, western Svalbard. Boreas 42, 532-543.

Alexanderson H., Landvik J.Y. \& Ryen H.T. 2011. Chronology and styles of glaciation in an inter-fjord setting, northwestern Svalbard. Boreas 40, 175-197.

Arnold L.J. \& Roberts R.G. 2009. Stochastic modelling of multi-grain equivalent dose $\left(D_{e}\right)$ distributions: implications for OSL dating of sediment mixtures. Quaternary Geochronology 4, 204-230.

Bronk Ramsey C. 2009. Bayesian analysis of radiocarbon dates. Radiocarbon 51, 337-360.

Duller G.A.T. 2008. Single-grain optical dating of quaternary sediments: why aliquot size matters in luminescence dating. Boreas 37, 589-612.

Fuchs M. \& Owen L.A. 2008. Luminescence dating of glacial and associated sediments: review, recommendations and future directions. Boreas 37, 636-659.

Fuchs M., Straub J. \& Zöller L. 2005. Residual luminescence signals of recent river flood sediments: a comparison between quartz and feldspar of fine- and coarsegrain sediments. Ancient TL 23, 25-30.

Guérin G., Christophe C., Philippe A., Murray A.S., Thomsen K.J., Tribolo C., Urbanova P., Jain M., Guibert P., Mercier N., Kreutzer S. \& Lahaye C. 2017. Absorbed dose, equivalent dose, measured dose rates, and implications for OSL age estimates: introducing the average dose model. Quaternary Geochronology 41, 163-173.

Landvik J.Y., Alexanderson H., Henriksen M. \& Ingólfsson Ó. 2014. Landscape imprints of changing glacial regimes during ice sheet build-up and decay: a conceptual model from Svalbard. Quaternary Science Reviews 92, 258-268.

Landvik J.Y., Bolstad M., Lycke A.K., Mangerud J. \& Sejrup H.P. 1992. Weichselian stratigraphy and palaeoenvironments at Bellsund, western Svalbard. Boreas 21, 335-358. 
Lycke A.K., Mangerud J. \& Sejrup H.P. 1992. Late quaternary foraminiferal stratigraphy from western Svalbard. Boreas 21, 271-288.

Mangerud J., Bondevik S., Gulliksen S., Hufthammer A.K. \& Høisæter T. 2006. Marine ${ }^{14} \mathrm{C}$ reservoir ages for 19th century whales and molluscs from the north Atlantic. Quaternary Science Reviews 25, 3228-3245.

Mangerud J., Dokken T., Hebbeln D., Heggen B., Ingólfsson Ó., Landvik J.Y., Mejdahl V., Svendsen J.I. \& Vorren T.O. 1998. Fluctuations of the Svalbard-Barents Sea ice sheet during the last 150000 years. Quaternary Science Reviews 17, 11-42.

Murray A.S. \& Funder S. 2003. Optically stimulated luminescence dating of a Danish Eemian coastal marine deposit: a test of accuracy. Quaternary Science Reviews 22, 1177-1183.

Murray A.S., Marten R., Johnson A. \& Martin P. 1987. Analysis for naturally occurring radionuclides at environmental concentrations by gamma spectrometry. Journal of Radioanalytical and Nuclear Chemistry Articles 115, 263288.

Murray A.S., Wintle A. \& Wallinga J. 2002. Dose estimation using quartz OSL in the non-linear region of the growth curve. Radiation Protection Dosimetry 101, 371-374.

Murray A.S. \& Wintle A.G. 2000. Luminescence dating of quartz using an improved single-aliquot regenerativedose protocol. Radiation Measurements 32, 57-73.
Murray A.S. \& Wintle A.G. 2003. The single aliquot regenerative dose protocol: potential for improvements in reliability. Radiation Measurements 37, 377-381.

Prescott J.R. \& Hutton J.T. 1994. Cosmic ray contributions to dose rates for luminescence and ESR dating: large depths and long-term time variations. Radiation Measurements 23, 497-500.

Reimer P.J., Bard E., Bayliss A., Beck J.W., Blackwell P.G., Bronk Ramsey C., Buck C.E., Cheng H., Edwards R.L., Friedrich M., Grootes P.M., Guilderson T.P., Haflidason H., Hajdas I., Hatté C., Heaton T.J., Hoffmann D.L., Hogg A.G., Hughen K.A., Kaiser K.F., Kromer B., Manning S.W., Niu M., Reimer R.W., Richards D.A., Scott E.M., Southon J.R., Staff R.A., Turney C.S.M. \& Van Der Plicht J. 2013. IntCal13 and Marine13 radiocarbon age calibration curves 0-50,000 years cal BP. Radiocarbon 55, 1869-1887.

Tabachnick B.G. \& Fidell L.S. 1996. Using multivariate statistics. New York: HarperCollins College Publishers

Thrasher I.M., Mauz B., Chiverrell R.C. \& Lang A. 2009. Luminescence dating of glaciofluvial deposits: a review. Earth-Science Reviews 97, 145-158.

Wallinga J. 2002. On the detection of OSL age overestimation using single-aliquot techniques. Geochronometria $21,17-26$. 